\title{
Penyalahgunaan Obat Kodein dan Tahapan Pembuktiannya: Tiga Laporan Kasus
}

\section{Codeine-Associated Drug Abuse and How The Investigation Stages: Three Case Report}

\author{
Ainun Jaryah Bahrir \\ Ilmu Forensik, Sekolah Pascasarjana, Universitas Airlangga \\ Email: ainun.jaryah-2017@pasca.unair.ac.id
}

\begin{abstract}
ABSTRAK
Kodein adalah alkaloid terkandung dalam opium sebesar 0,7$2,5 \%$, selain itu alkaloid kodein juga ditemukan dalam opioid sekitar 0,3$3,0 \%$. Kodein merupakan obat analgesik golongan opium yang biasa digunakan untuk penghilang rasa nyeri dari sedang hingga berat. Kodein merupakan obat yang paling banyak digunakan dikalangan praktisi kesehatan. Kodein yaitu sejenis obat batuk, namun dapat menyebabkan ketergantungan/efek adiksi sehingga peredarannya dibatasi dan diawasi secara ketat. Dalam menggunakan suatu obat, tidak hanya manfaat terapi dari obat itu yang dipertimbangkan tetapi juga efek samping yang ditimbulkannya. Kodein merupakan salah satu jenis NAPZA golongan depresan. Depresan adalah senyawa yang dapat menekan sistem tubuh. Depresan Sistem Syaraf Pusat (SSP) adalah senyawa yang dapat menurunkan aktivitas fungsional dari Sistem Syaraf Pusat (SSP). Akibatnya yaitu menurunnya fungsi beberapa organ tubuh. Depresan Sistem Syaraf Pusat (SSP) bekerja dengan menekan pusat kesadaran, rasa nyeri, denyut jantung dan pernafasan. Telah dilaporkan beberapa kasus penyalahgunaan kodein hingga menyebabkan kematian. Maka dari itu tujuan dari artikel ini untuk memaparkan tentang kodein dan bagaimana tahapan pembuktian kasus penyalahgunaan dengan menggunakan tiga laporan kasus yang telah ada.
\end{abstract}

Kata kunci: kodein, analgesik, penyalahgunaan obat, studi kasus

\begin{abstract}
Codeine is an alkaloid contained in opium of $0.7-2.5 \%$, besides that codeine alkaloids are also found in opioids around $0.3-3.0 \%$. Codeine is an opium analgesic drug commonly used for moderate to severe pain relief. Codeine is the most widely used drug among health practitioners. Codeine is a type of cough medicine, but can cause addiction so that circulation is limited and closely monitored. In using a drug, not only the therapeutic benefits of the drug are considered but also the side effects it causes. Codeine is one type of drug depressant group. Depressants are compounds that can suppress body systems. Central nervous system
\end{abstract}


(CNS) depressants are compounds that can decrease the functional activity of the central nervous system (CNS). The result is a decrease in the function of several organs of the body. Central nervous system (CNS) depressants work by suppressing the center of awareness, pain, heart rate and breathing. Several cases of codeine abuse have been reported to cause death. Therefore the purpose of this article is to explain about codeine and how the stages of evidence of abuse are used by using three existing case reports.

Keywords: codeine, analgesic, drug abuse, study case

\section{INTRODUCTION}

Toxicology is the science of chemical compounds that are harmful to humans and animals (Mutschler, 1991). Forensic toxicology is a science of toxicology that can be utilized in the interests of the judiciary. The main work of forensic toxicology is to carry out qualitative and quantitative analyzes of poisons with physical evidence and translate the results of the analysis. Forensic toxicology consists of three parts, applied natural science in the analysis of poisons as evidence of crime, detect and identify concentrations of poisons and their metabolites in biological material, and interpret the results of the analysis into an argument about the cause of poisoning (Melina et al., 2014).

Codeine is an alkaloid contained in opium of $0.7-2.5 \%$, is a natural opium that is widely used for medical purposes. Opium is the sap of Papaver somniferum seed which is not yet ripe and is dried at room temperature. Opium contains more than 20 alkaloids, the content of which can vary greatly. The main alkaloid is morphine. As side alkaloids are narcotics, codeine, papaverine, and thebaine. (Mutschler, 1991).
Codeine is an alkaloid which is also found in opioids, around 0.3 $3.0 \%$. Codeine is an analgesic drug commonly used for pain relief from moderate to severe. Codeine is most often used as a cough medicine by doctors, but can cause addictive effects so that their circulation is limited and closely monitored. Codeine is included in group III narcotics, narcotics which have low dependency power and include depressant groups. A compound that can suppress body systems. Central Nervous System Depressants (CNS) are compounds that can decrease the functional activity of the Central Nervous System (CNS), resulting in decreased function of several organs of the body. Central Nervous System Depressants works by pressing the central part of awareness, pain, heart rate and breathing (Melina et al., 2014).

It's just that codeine is made by the semi-synthesis process of morphine through methylation. The analgesic working power is smaller than morphine so to increase it needs to be mixed with other analgesics (antipirin, phenasetin, quinine) The analgesic effect of codeine depends on the conversion of codeine to morphine. Only about $5-10 \%$ of the codeine is 
converted to morphine, the rest will be converted to inactive metabolites to be excreted (Wiryowidagdo, 2000; Mayangsari and Rostinawati, 2017).

In using a drug, not only the therapeutic benefits of the drug are considered but also the side effects it causes. Several cases of codeine abuse have been reported to the point of causing death. Therefore the purpose of this article is to explain about codeine, and how the investigation stages using three case report.

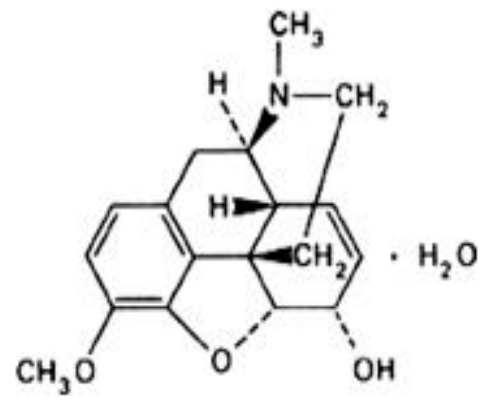

Figure 1. Codeine Chemical Structure (image source: mipa-farmasi.com)

Codeine is called metal morphine or morphine monometiler. Another name for codeine, i.e 7,8Didehidro-4,5a-epoksi-3-metoksi-17metil morfinan $6 \alpha$-ol monohidrat. Codeine is soluble in water and very soluble in hot water, difficult to dissolve in ethanol but will be more soluble in boiling ethanol (Farmakope Indonesia, 2014).

Codeine is available in free base form or in the form of $\mathrm{HCl}$ or phosphate salts. The dose of codeine as an antitussive is $10 \mathrm{mg}$ for adults. This dose is equivalent to a morphine dose of 2-4 mg (Ganiswarna et al., 1995).
Pharmacodynamics is the science of where the drug process happen and how and why pharmacological effects occur (Mutschler, 1991).

a. Central Nervous System (CNS) Codeine is the most widely used antitussive. The effects of codeine on CNS include analgesics. Analgesics by morphine and other opioids have arisen since before the patient sleeps and often analgesics occur without sleep. Through the esterification of the phenol hydroxyl group from morphine, analgesic work is weakened, instead antitussive work still exists. When there is a decrease in analgesic work, the side effects also decrease.

b. Analgesic

The analgesic effects of morphine and other opioids are very selective, other sensory functions such as touch, vibration, vision and hearing do not experience any changes. Analgesic effects appear based on three factors: morphine leaves excitatory pain, morphine can affect emotions, morphine eases sleep and during sleep excitatory pain increases.

c. Excitation

Factors that can change the effects of morphine excitation are idiosyncracy and CNS reflex excitatory level. Codeine does not cause depression when the dose is raised, but causes excitation. 


\section{METHOD}

This research is a case study on codeine-associated drug abuse and how the investigation of the case is. Data collection was carried out through literature studies on cases of codeine abuse, and the stages of case investigation.

In the data collection stage, researchers used three case report from the Journal of Morphine/codeine ratio, a key in investigating a case of doping by Seif-Barghi, Moghadam, and Kobarfard. The Journal of "Tampering to Death": A Fatal Codeine Intoxication Due to a Homemade Purification of a Medical Formulation by Fais. et al. And the jurnal of Codeine-spiked Beer Journal in a date rape case? by Havig, Wiik, Karinen, Brochmann and Vevelstad as primary data regarding cases of codeineassociated drug abuse.

While the subject regarding the stage of case investigation uses the jurnal of Skring Test and Codeine Determination with Spectrophotodensitometry TLC by Sari, Pande and Leliqia, Ni Putu.

The data is then analyzed to get the right conclusions about the cases of codeine abuse, and the stages of case investigation.

\section{RESULT AND DISCUSSION}

Codeine is different from other narcotics, codeine is a drug that is classified as a drug that is less dangerous compared to other opiates. The drug does not belong to a class that is strictly prohibited as reported by INCB and WADA (WADA 2018) (INCB 2017b). Codeine is Narcotics
III group whose addictive effect or dependency effect is still in the lower limit compared to other narcotics groups (INCB 2017a). codeine is Narcotics III group whose addictive effect or dependency effect is still in the lower limit compared to other narcotics groups, but several cases of codeine abuse that cause criminal acts have been found (Seif-Barghi et al. 2015; Havig et al., 2016).

These rapid changes are studied both in living and dead individuals, but an increase in metabolism is found in the deaths of individuals examined for autopsy. This significant change, made investigators and scientists to be careful when interpreting cases of protein, morphine and heroin (Berg-Pedersen et al., 2014).

The cases below are presented on both sides of the codeine, and a thorough examination must be considered when examining: as an analgesic drug, causing an addiction or agent violation.

\section{CASES OF CODEINE DRUG ABUSE. Case 1}

This case presents codeine in terms of good use and is recommended for medical purposes which then results in the alleged Doping intention by Seif-Barghi et al. (2015). This examination is based on a ban on the consumption of narcotics for sport (doping) against athletic challenges, Iran.

According to Seif-Barghi et al, the results of urine sample analysis showed that codeine was used as a 
doping case in a 25-year-old Futsal Premier League player in 2014-2015. The Athlete does not have a history of violating anti-doping regulations. The person was randomly selected for sampling during the match in mid2014.

The urine sample was morphine positive, and allegedly violated Article 6 of FIFA's antidoping regulations. FIFA's antiregulation rules refer to WADA's prohibited list of prohibited drugs.

The player said he did not use narcotics including morphine in the testimony but admitted that he had taken a number of acetaminophenin tablets $(300 \mathrm{mg}$ and $10 \mathrm{mg}$ ), the day before because of a toothach. Morphine and codeine concentrations reported in the urine sample were 54.5 $\mu \mathrm{g} / \mathrm{ml}$ and $52.7 \mu \mathrm{g} / \mathrm{ml}$, respectively, the Mor / Cod ratio was 1.03.

\section{Codeine abuse result}

The results of the investigation concluded a study of similar properties that regulate consumption 24 hours before consolidating the Morphin / codein ratio (1.03). So the analysis proves that the athlete consumed codeine 24 hours ago. Also taking into account the fact that codeine was not among WADA 2015 and was also not included in the list of illegal drugs in 2018, positive results for morphine in urine samples were distributed for codeine consumption. Therefore, the disciplinary committee concluded that the player did not violate anti-doping regulations by specifying how the prohibited substance entered the system and had no intention of increasing performance. Therefore, according to article 21 of FIFA's anti-doping regulations, doping cases are closed (Seif-Barghi et al., 2015).

\section{Case 2}

Case 2 is based on purifying codeine from a compound formulated to obtain pure codeine for intended recreational using. Fais et al. (2017) "interference with death: fatal codeine poisoning due to self-purification of medical formulations."

A case report of a 41-year-old white man found unresponsive in his apartment displaying reddish-brown liquid coming out of his mouth and nose. No evidence of physical injury was identified.

At the scene, uneven pharmaceutical opioid blisters, medical formulations containing $500 \mathrm{mg}$ acetaminophen and $30 \mathrm{mg}$ codeine per tablet, used coffee filters covered with white marshmallow-like substances, pans, and small jars containing residues from clear liquids, found on the table the kitchen near the victim's place. This case is a further practice of the many self-purification of medical formulations using guidelines available on the Internet for the purpose of drug abuse, where internet "forums" claim to be able to purify codeine by removing additional substances, such as acetaminophen, to avoid or limit side effects. In this case, investigation suggested a fatal codeine intoxication after the tampering procedure called "cold water extraction." 
As is known, codeine (3methylmorphine) is a weak opiate, which displays effects such as morphine euphoria and is medically prescribed can be combined with other active addictive substances, such as acetaminophen and / or ibuprofen, for analgesics, antitussives, and diarrhea purposes. This pharmaceutical formulation is generally considered safe and is not suitable for infringement purposes.

Indeed, a low amount of codeine, about ten times below the appropriate dose is used to get euphoric experience, but when combined with high-dose addictive substances, will produce side effects, such as gastrointestinal bleeding, nephrotoxicity, hypokalemia, and acute hemorrhagic necrotizing pancreatitis.

\section{Codeine abuse result}

Examination findings obtained from autopsy and toxicological analysis of postmortem blood and urine indicate the presence of ethanol and opiates. Marshmallow-like substances are filtered out and a high amount of acetaminophen is found, while codeine is detected as the main constituent of purified liquid, the liquid is clearly found in the jar. Thus, the results of body examinations and analysis of non-biological material from bodily fluids of the deceased turned out to be integrated with information collected on investigations of death events which confirmed the self-purification of codeine poisoning.

The report underlines the importance of considering the harmful effects of codeine even though it is found in a small percentage and the tight link between crime and legal drugs to identify the cause of death and the reconstruction of case events in the field of forensic chemistry.

\section{Case 3}

This case discusses the codeine abuse in a rape case reported by a Norwegian criminal case by Havig et al. (2016) in "Codeine-spiked beer in a date rape case? The report is a case of alleged sexual violence facilitated by drugs (DFSA), which involves codeine and acetaminophen which are likely mixed in beer.

Analysis of the alleged DFSA case was carried out at the Norwegian Institute of Public Health (NIPH), which showed low levels of codeine and acetaminophen in blood samples collected several hours after the victim consumed the drug accidentally. The victim herself claimed not to suspect that she had swallowed a drink that had been given medicine and there was no use of the drug before the attack. According to the report, the victim claimed to have experienced interference after consuming nearly two beers in a bar.

Previously, the victim left the rest of the second beer unattended while visiting the toilet, and added that the victim immediately finished the last beer when he returned. In the blood of the victim there is a combination product of cetaminophen codeine. Considering the possibility that the victim's last beer had been affixed with the codeine provided, several questions were asked: (1) Do 
drugs that contain codeine actually dissolve in beer? (2) What concentration of codeine can be achieved with beer and how quickly can it occur? (3) Does spiking with drugs that contain codeine, have visual changes or changes in the taste of beer? And (4) Does the consumption of codeine-spiked beer causing damage or disability?

A small study was conducted to examine this case, spiking beer with preparations containing codeine and acetaminophen and then observe the concentration, appearance, and taste of the solution. The results of the study stated that most preparations dissolve quickly in beer, reaching high concentrations, but at the expense of strong taste and dramatic changes in beer.

\section{Codeine abuse result}

This research was conducted to assess whether drugs containing codeine, which is most commonly used and available legally for purchase in Norway, can dissolve in beer; codeine concentration that can be achieved at different time points; if spiking can produce visual changes or changes in the taste of beer; and if ingesting $250 \mathrm{~mL}$ of beer containing codeine can cause damage or disability.

Finally, the results clearly show that most of the drugs containing codeine tested quickly dissolve in 250 $\mathrm{ml}$ of beer. The highest concentration is achieved with a clear maximum concentration for all solutions achieved in 5 minutes. However, spiking produced noticeable changes for all the preparations tested, and also changes in taste. Later it was discovered that some people were genetically unable to feel bitter taste, making them less likely to pay attention because of codeine or acetaminophen.

Therefore, consuming $250 \mathrm{~mL}$ of beer and retrace the highest concentration detected in the report, resulting in consumption of codeine $450 \mathrm{mg}$, which causes symptoms of poisoning and severe death.

Despite the fact that codeine seems to dissolve in beer and large amounts can be swallowed, the report concludes that it is not possible to consume that amount by the victim because of noticeable changes in the appearance and taste of beer. However, if poor lighting or concentration of alcohol in the victim's blood is high, however, it can make the victim unaware of the change in color and taste of the beer. So the conclusion in this case is that codeine is used as a rape tool.

\section{Codeine Dose}

At usual doses for those who suppress coughing, codeine does little to inhibit the respiratory center and does not cause euphoria. Therefore addiction is rare. As a side effect can occur nausea and weak obstipation (Mutschler, 1991).

\section{THE INVESTIGATION STAGES}

Codeine is an alkaloid obtained from opium or prepared from the methylation process of morphine. Codeine can be found in the use of 
illegal heroin, where illegal heroin usually contains 3-acetylcodein.

Furthermore, in the body of acetyl codeine will be metabolized into codeine (Sari and Leliqia, 2013) thus the codeine compound can be used as a marker in the case of heroin use, in which the development of code testing and determination of codeine by the TLC-spectrophotodensitometry

method will be very useful in the field of forensics.

This toxicology or forensic toxicology analysis has three main steps, namely sample preparation, differentiation (screening and confirmation), identification and determination. Sample preparation aims to reduce the presence of confounding compounds found in the sample matrix. Meanwhile, differentiation aims to identify the appropriate components in the minimum amount. The easiest methods to use are immunoassay and thin layer chromatography (TLC). TLC is an analytical method that is relatively inexpensive and easy to work on (Sari and Leliqia, 2013).

Codeine can also be obtained and medically approved for medical uses such as analgesics. In that form, codeine is usually produced in a combined formulation with acetaminophen, aspirin or ibuprofen (to reduce the concentration of adverse euphoria effects). Also, in processing samples for codeine analysis, blood and urine tests are the preferred and effective collection of samples for checking codeine ingested.

\section{CONCLUSION}

Codeine is an alkaloid contained in opium of $0.7-2.5 \%$ is a natural opium that is widely used for medical purposes. Codeine is included in class III narcotics, namely narcotics which have low dependency power, which are widely used in medicine and for scientific purposes.

Codeine is used as a basis for making antitussive dihydrocodone and hydrocodone and analgesic oxycodone. Codeine compounds can be used as a marker in the case of heroin use, in which the development of codeine screening and determination tests with the TLCspectrophotodensitometry method will be very useful in the forensic field.

Because the circulars are still easily accessible, many people misuse codeine, several criminal cases have been found using codeine as a tool of crime.

\section{SUGGESTION}

Codeine is a type of cough medicine that is used by doctors, but can cause dependence and poisoning if its use is not dose-appropriate or abuse. This poisoning can cause various symptoms ranging from mild to death, so that circulation is limited, closely monitored and according to doctor's prescription.

In Indonesia, cases of codeine abuse are still under supervision by the National Narcotics Agency (BNN), several national brand cough medicines are given a warning because there have been victims of addictive substances. It is expected that more research on similar cases that are still 
foreign is handled in Indonesia, as a form of learning more effective handling, so as to produce conclusions in accordance with the constitution in Indonesia.

\section{REFERENCES}

Badan Narkotika Nasional Republik Indonesia. 2004. Pedoman Pencegahan Penyalahgunaan Narkoba Bagi Pemuda.

Berg-Pedersen, R.M. et al., 2014. Codeine to morphine concentration ratios in samples from living subjects and autopsy cases after incubation. Journal of Analytical Toxicology, 38(2), pp.99-105.Ganiswarna, S. 1995. Farmakologi dan Terapi. Edisi keempat. Gaya Baru. Jakarta.

Fais, P. et al., 2017. "Tampering to Death": A Fatal Codeine Intoxication Due to a Homemade Purification of a Medical Formulation. Journal of Forensic Sciences, 62(6), pp.1671-1673.

Ganiswarna S (1995). Farmakologi dan Terapi. Jakarta: Gaya Baru.

Havig, S.M. et al., 2016. Codeinespiked beer in a date rape case? International Journal of Legal Medicine, 130(6), pp.1513-1518. Available at: http://dx.doi.org/10.1007/s00414 -016-1340-5.
INCB, I.N.C.B. (United N., 2017a. List of Narcotic Drugs under International Control. , pp.1-23.

INCB, I.N.C.B. (United N., 2017 b. Psychotropic Substances.

Keputusan Menteri Kesehatan Republik Indonesia tentang Farmakope Indonesia Edisi V

Mayangsari, Annida dan Rostinawati, Tina. 2017. Polimerfisme CYP2D6 dan Pengaruhnya terhadap Metabolisme Kodein. Farmaka. Vol 4(4).

Mutschler E (1991). Dinamika Obat. Bandung: Penerbit ITB.

Sahurrahmanisa dkk. 2017. Efek Kombinasi Parasetamol dan Kodein sebagai Analgesia Preemptif pada Pasien dengan Orif Ekstremitas Bawah. Berkala Kedokteran. Vol 13(1):97-104.

Sari, Pande Made Nova Armita dan Leliqia, Ni Putu Eka. Uji Skring dan Determinasi Kodein dengan TLC Spektrofotodensitometri. IFJLS. 3(1):26-31.

Seif-Barghi, T., Moghadam, N. \& Kobarfard, $\quad$ F., 2015. Morphine/codeine ratio, a key in investigating a case of doping. Asian Journal of Sports Medicine, 6(4), pp.10-12. 